\title{
U.S. Empire: Divergent Views
}

\author{
Alida TOMJA \\ "Aleksander Moisiu" University \\ Email: alidatomja@hotmail.com
}

Daniel BORAKAJ

"Aleksander Moisiu" University

Email: daniel_borakaj05@yahoo.com

\begin{abstract}
The restructuring of the international order at the end of the Cold War created a unipolar system with the United States at the top, but at the same time, restored the language of empire and their categorization as an imperial power. Moreover, the foreign policy pursued by George W. Bush administration after September 11, 2001, prompted many researchers to describe the US role in the world as inseparable from this term. The debate is widely increased in recent years and the dilemma is whether to refer them as imperial or hegemonic power of this system. If it's hegemonic nature would be purely obvious, then how can be explained that many researchers do not hesitate to define America as empire, especially after September 11, 2001? Based on the literature that deals with the US imperial character, this paper aims to answer the above questions, and to highlight that United States, do not possess anything as an imperial power beyond their Republican core.
\end{abstract}

Keywords: United States of America, imperialism, empire, hegemony

\section{Introduction}

Concerns about how operates a unipolar world and the single pole of the system, constitute the main lines of the global political debate in the early 21 st century. Many political commentators, historians, politicians, both inside and outside the US, in efforts to understand the international system dominated by them, continued to discuss american history and the socalled "imperial dimensions" of the latter, using a variety of terms such as empire, hegemony, colossus or imperial power.

Describing America as the empire of our days has become fashionable among researchers. For some of them, here can be mentioned Chalmers Johnson, America needs a long time to be called so (Johnson 2004: 2), while, for some others, United States are living a transition from Republic to Empire (Garrison. 2004: 4-5). There are also authors who openly designate it as an empire, as Andrew J. Bacevich, Jim Garrison, Lloyd C. Gardner and Marilyn B. Young, Chalmers Johnson, James Petras and Morris Morley (Bacevich, 2002, Garrison. 2004 Lloyd C. Gardner \& Marilyn B. Young, 2005, Johnson 2004, James \& Morris. 1995), or use the term "Colossus", as Joseph Nye and Niall Ferguson. While, for most authors, among them: Charles-Philippe David, David Grondin, Rosemary Foot, S. Neil MacFarlane, Michael Mastanduno and many others, United States do not constitute empire, but a hegemonic superpower.

Accusation against American imperialism, have historical roots and are not limited to the development of the 21st century or after September 11. However, there are some differences between the notion of American Empire used many years ago and what is spoken today. Today, America is the only superpower in the world. Military, economic and cultural power, of these states are essentially unsurpassed and uncontroversial, therefore, many scholars do not hesitate to define them as empire, writing for their "imperial" features. But did these features really characterize US foreign policy? Let's handle this issue below. 


\section{Reflections on "imperial" features}

Imperialism is a term, which mainly relates to the nineteenth century Europe and to the trend of that period to create empires. Its negative connotation hints colonialism, civilizing missions and chauvinism, making it a despised phenomenon. At the end of the nineteenth century, imperialism became synonymous not only to the territorial expansion but also to the colonial oppression (Gilden 1987: 333-50). So, expressed simply, Empire means a system characterized by realistic military and territorial dimension, by dominance over other players of the international system, failing to refer their voluntary and submission obedience. Therefore is not surprising that Americans not only reject this phenomenon, but oppose all those scholars who try to portray them as an imperial empire, pointing out that this phenomenon is contradictory to the whole values upon which they are founded.

In the late 1980s, before the end of the Cold War, Susan Strange, used the concept of a "non-territorial empire" (Strange 1988: 7), to describe the system of domination imposed by the United States after World War II. However, although American history has not been a territorial expansion power, can not be denied the fact that America has dominated the world militarily and economically. According Shephen S. Shalom, even United States have never been a great official empire like Britain, have shown imperial nature, which has been mostly informal and neocolonial. This means that although USA in generall has not intended to set remote territories under their legal control, they maintain and expand economic domination over as many countries they could (Shalom 1993: 8). Another group of researchers defend the idea that United States have been expansionist power during the 19th century, especially between 1807 and 1904. Hurell, as one of the authors that supports this line of thought, says that, after the victory of the Spanish-American war of 1898, the United States established protectorates in Cuba, Haiti, Nicaragua and the Dominican Republic, by interfering repeatedly in the internal affairs of Central American and Caribbean countries (Hurrell 2007: 267). But realistically this is the only short imperial classic period for the United States, which realized that, instead of occupying territories and becoming an imperial power, they could benefit more by developing trade links with the world.

In contrast to the founding fathers, a good part of researchers who argue that the United States should be considered empire, imply a modern version of the latter that differs from its traditional meaning. A interesting view on this issue is provided by Jim Garrison. The alternative term that he attributes to the United States is a imperial republic. According to him, the true essence of empire is the control of one nation over all other nations. Although America remains a republic within its borders, it has become an empire in relation to the rest of the world, in this sense, America is an imperial republic. Indeed, he goes even further, stating that:

Whatever qualms people may have about it, America has become an empire, and there is no turning back. The transition from republic to empire is irreversible, like the metamorphosis from caterpillar to butterfly. Once power is attained, it is not surrendered (Garrison 2004: 4-5).

Garrison continues to indicate that United Kingdom learned the meaning of empire to America, but the focus of the last one has never been territories. The modern version of empire view, not with the same meaning of the previous times, is found even to Michael Ignatieff, according to which:

The 21 st century imperium is a new invention in the annals of political science, an empire lite and a global hegemony whose grace notes are free markets, human rights and democracy, enforced by the most awesome military power the world has ever known (Ignatieff 2003).

In fact, american foreign policy, more than territorial claims or foreign countries administration, aimed to use their military power in function of free markets and commercial advantages. However, Garrison points out that whether or not America represents a new kind of empire, above all, remains a state carved in the list of dominant powers that have shaped history. 


\title{
9/11 and the American Empire
}

Should be noted that a considerable part of the studies, connect the imperial character of the United States specially with the foreign policy pursued by the latter after the terrorist attacks of September 11. However, despite of any political affiliation, establishing United States as an empire only as a result of recent phenomena associated with September 11, subsequent declarations of war against terrorism, or military intervention in Iraq, is clearly insufficient definition, limited, but above all, incorrect. US military intervention in Iraq, as was proved later, had not intended to deploy a colonial rule over the territory, but to export the values and political principles, that American world respects by being liberal democracy.

Immediately after September 11, 2001, Max Boot emerge as one of the most vocal supporters and optimistic to American foreign policy. In the article, the U.S. Imperialism: A force for good, Max Boot argues as follows:

\begin{abstract}
U.S. imperialism has been the greatest force for good in the world during the past century. It has defeated Communism and Nazism and has intervened against the Taliban and Serbian ethnic cleansing. Along the way, it has helped spread liberal institutions to countries as diverse as South Korea and Panama. (Boot 2003: 15).
\end{abstract}

At this way, Max Boot is among those researchers who supported US intervention in Iraq, and the so-called unilateral war with the latter. Robert Duarric and William Odon are two other authors who, commenting US military interventions in Afghanistan or Iraq, try to understand their impact on America, by not considering them as evidence of its imperial power. According to them, external challenges are not a serious threat to the United States, neither emerging powers like China, Al-Qaeda or other similar non-governmental organizations. They can cause damage, but no way destroy the American empire (Duarric \& Odon 2004: 7). By these researchers logic if Iraq will rise up as stable state willing to cooperate with the United States, and if other regional countries like Syria and Iran do the same, it will only empower more the American empire (ibid: 208). Meanwhile, the policy pursued by the US in the Middle East, according Duarric and Odon, more than obedience to US imperial or colonial tendency, threatens the continuation of its domination or global leadership.

Another author who devoted special attention to the American empire issue is Noam Chomsky, known as an anarchist and social-liberal in the same time. Chomsky argues that before U.S entered in the war [World War II], analysts concluded that in the postwar world they will aim to enjoy undisputed power, limiting the sovereignty of those countries that would interfere their global plans (Chomsky 2003: 15). According to him, the imperial strategy of the US is clearly based on the National Security Strategy of 2002. The particularity of W. Bush administration's foreign policy followed after September 11, stands at willingness to act based on this strategy but with more determination and ferocity (ibid).Chomsky's work on this issue has led to the creation of 17 volumes in late 2007, with the co-author Chalmers Johnson. According to the latest, American empire roots predate September 11, concretely with the "Monroe Doctrine" of 1823, when United States decided all Latin America under their influence sphere. By this author, the fact that the US has established more than 725 bases worldwide, qualifies America as an empire, regardless of whether or not it has annexed territories (Chalmers 2004: 23).

Even British journalist Jonathan Freedland has maintained a critical stance on US foreign policy after September 11, 2001. Freedland argues that this policy crowned by the invasion of Iraq, is essentially non-American. In his article, Emperor George, Freedland argues that Bush administration and the Iraq War, are not typically American, on the contrary, in every direction are almost exceptions to American rules. According to him, aggressive foreign policy of the USA actually creates the idea of imperial behavior, but the latter is simply a consequence of the superiority of George W. Bush and his neoconservatives followers because the United States have never been a colonial power (Freedland 2003). Naill Ferguson as Max Boot and Paul Johnson, thinks that there is nothing inherently wrong with being Empire as long as the latter serves the needs of the metropolis and periphery. The author rejects the idea that all empires have exploiter character claiming that may exist liberal empires that enhance their security and prosperity, providing public goods to the rest of the world. In his view, America is an informa-liberal empire which the world needs, a blessing power in a world dominated by religious conflicts, violence and political oppression (Ferguson 2004: 10). 
Contrary to most of above authors, national security adviser Condoleezza Rice, asked in 2003 by a German team news if America can be compared with the Roman Empire, responded clearly against this comparison: the United States never had but neither have imperial ambitions. Similarly, Secretary of Defense Donald Rumsfeld was asked by a reporter of AlJazeera in 2003, if the United States had deployed to Iraq to build an empire. His insistent response was: US are not colonial power, we have never been so. America does not use power to go around the world in an attempt to acquire their wealth and resources. We have never done and we will never do something like that, because this is not how democracies behave (ibid: 1). However, despite various claims of academics to define it as traditional or modern Empire, hegemony or, as Ferguson called it, a-monster-hegemonic power, what remains indisputable is their unprecedented power. Therefore, by this point of view, are eligible some researchers who raise the question: if the United States can not be described as an empire then what nation could be? The fact remains that they are consolidated as the world's major global power, able to exercise it at a much higher level than any other nation, reigning supreme in all dimensions of military, economic, political, technological and cultural power. Many researchers, comparing the nineteenth century Britain to the United States, come to the conclusion that, while the British Empire never really enjoyed the hegemonic status, the United States, as mentioned above throughout this paper, since the War II qualified solidly as global hegemonic power manifested through economic domination, forming the framework of world trade, the dollar hegemony, as well as in other military, technological and cultural areas. In closer military terms the Cold War raised United States in the position of unquestioned leadership (Gaddis 2004: 29-30).

It is already known that one of the principles of international state system operation, is the countries differentiation based on their strength. In this sense, the international state system is hierarchical, it begins with the most powerful state in top and ends with the less powerful one in the end, depending on the specific position of their power. As mentioned above, the unique place of the United States is widely accepted in this hierarchical structure of the international relations system, even the fact that there is a deep gap between them and other major powers in the system.

\section{Not an Imperial but a Hegemonic Power}

Contrary to the authors analyzed until now, another group of scholars are not agree to classifie United States as imperial power. According to them US are the only global hegemonic power. But what should be understood by the latter? What are the components that determine the status as single hegemonic power of the world? The concept of hegemony in international relations system actually suffers by the problem of definition. Some researchers define it broadly, including all the attributes of state power as economic production and productivity, military power, but also the ideological and cultural one. Other scholars, mainly realists, tend to privilege more military force while the institutional neo-liberalism focuses on cooperation and interdependence issues of the global economy. According to the latter, hegemony is a situation in which a state is so powerful, able to determine and control the implementation of the basic rules that regulate interstate relations, but above all, that have the will to do it (Keohane 1984: 34-5).

However, despite the conceptual confusion created, remains clear that hegemony consists in the possession and command of a multidimensional set of power sources. John Mearsheimer, Andrew Gamble, Robert O. Keohane, and Robert Gilpin are a group of scholars try to clarify this notion. According to these authors, hegemony firstly relates to the strong power of a state, understood in military and economic terms. Militarily, a hegemon skills are at a level that no other country can fight against him (Mearsheimer. 2001: 40); enjoys economic supremacy in the international system and leads to material resources (Gamble in Patrick Karl \& Armand Clesse 2002: 130) Secondly, hegemony means ambition to be the dominant power, to maintain security, economic and ideological interests (Gilpin 1981: 29-30). Thirdly, hegemony has to do with polarity. The hegemonic state, because of the military and economic unrivalled advantages, is the single largest power of the system, the only polar actor (Mearsheimer 2001: 40), creating a unipolar international system. Fourthly, hegemony has to do with the will. A hegemon must be willing to use his inaccessible power to impose order in the international system (Keohane \& S. Nye, 1977: 44). Finally, hegemony means comprehensive changes to the international system structure. At the time that a state wins this status, the system ceases to be anarchic, turning into hierarchical (Mearsheimer 2001: 34).

Other approaches, especially Antonio Gramsci, highlights the ideological dimension of hegemony as consensual domination. Aaccording to him, hegemony means a dominant force that use not only the military means, but also the ideological sources as very important to structure others competing behaviors and choices. In this way, are favored the most powerful interests and especially its desire to be more prominent actor (Iseri 2007: 94). Almost in the same line of thought is Immanuel Wallerstein, who clarifies that hegemony is a situation in which a country is able to impose its rules in the interstate system, creating a political order in favor of its interests. Hegemonic state enjoys additional advantages for 
offered or protected enterprises, advantages which are not accorded by the "market", but earned by its political pressure (Wallerstein 2002: 357). Meanwhile, according to Kenneth Waltz, power that enjoys a hegemonic power does not mean that the state possesses the ability to shape the international system according to its interests at all times (Waltz, 1979: 191-192). For the well known researcher Joshua S. Goldstein, hegemony has to do with the state that is able to detect, or at least to dominate the rules and agreements through which are realized international political and economic relations. According to this author, the economic hegemony means the ability to focus the world economy about yourself, whereas political hegemony means the ability to dominate the world militarily (Goldstein 1988: 261).

As we see, the most of these definitions reflects the role that the United States actually have in today's global system. Joseph Nye's assertion that, since the Roman Empire there has not been a great nation to be established so powerfully over others (NYE 2002-03: 545) is widely accepted.

However, this author trying to mitigate Goldstein's definition, argues that if hegemony is defined in a modest way as the situation where a country has significantly more sources of strength or abilities than others, then this simply means American prevalence and not necessarily domination or control (ibid: 558). Nye, rightly, mention several cases during the last decade, where the United States have not been able to control or dictate events in accordance with their preferences. However, this fact does not make it a less hegemonic state. United States are qualitatively differentiated from other countries, owing to a decisive political, economic, military, technological and cultural power. This fact is reinforced even further, if we refer to Zbigniew Brzezinski's that United States is and will remain the first global superpower, the only and last.

\section{Conclusions:}

In this point of view, the debate raised above, the imperial empire or hegemony, has been sufficiently constructive. In the context of this dilemma, the answer is clearly negative:

- the United States is not an empire, do not possess anything like an empire beyond their core Republican. In technical terms, can not be called either "imperial republic".

- in the most basic terms the international relations system of this century does not appear seduced by archaic tastes of territorial conquest, it is even hard to imagine any realistic scenario that showed this principle as desirable and workable.

- should be clear that US is a protector of the territorial status quo of this international system;

- although they are a superpower, as many scholars have convincingly dubbed empire, they are not land- grabber, do not have territorial ambitions, and never have intended territorial expansion;

- in contrast to other imperial powers of modern international history, the United States does not need to annex the territory of other states to consolidate their wealth or military capabilities;

- even in those countries where Americans have installed their military bases, did not intend their colonization, but creating conditions to establish democratic institutions by which will derive the security and stability;

- most great powers possess commercial nuclear power that makes possible their

immunization against invasion.

Therefore, it is unlikely that the US ever become an "imperial republic" in the traditional sense of the term, following the footsteps of the ancient city-states, which transformed their hegemony in the empire. This title could possibly be linked to the United States of 1803 or 1898 years, but not to the America of today. Its hegemonic power is not an illusion but a product of two very important factors. Firstly, the United States enjoys superiority in military, economic, technological, cultural and geopolitical power and secondly, since the collapse of the Soviet Union has not born any other power able to challenge it, in all dimensions of power components.

\section{Bibliography:}


[1] Bacevich, Andrew J. 2002, American Empire. The Realities and Consequences of U.S. Diplomacy. Cambridge, Mass: Harvard University Press.

[2] Boot, Max. 2003. "U.S. Imperialism: A Force for Good", National Post, 13 May.

[3] Chalmers, Johnson. 2004. The Sorrows of Empire: Militarism, Secrecy, and the End of the Republic. New York: Metropolitan Books.

[4] Chomsky, Noam. 2003. Hegemony or Survival: America's Quest for Global Dominance. New York: Metropolitan Books

[5] David, Charles-Philippe \& Grondin, David. 2006. Hegemony or Empire? The Redefinition of US Power under George W. Bush. Aldershot: Ashgate.

[6] Duarric, Robert \& Odon, William. 2004. America's Inadvertent Empire. New Haven: Yale University Pres.

[7] Ferguson, Niall. 2005. Colossus. The Price of America's Empire. New York: The Penguin Press.

[8] Freedland, Jonathan. 2003. "Emperor George", The Guardian, 2 April.

[9] Foot, Rosemary. MacFarlane, Neil S. Mastanduno, Michael. 2003. US Hegemony and International Organizations. The United States and Multilateral Institutions. New York: Oxford University Press.

[10] Garrison Jim. 2004. America as Empire. Global Leader or Rogue Power?, San Francisco: Berrett-Koehler Publishers.

[11] Gardner, Lloyd C. Young, Marilyn B. 2005. The New American Empire. New York: The New Press.

[12] Gildea. Robert 1987. Barricades and Borders. Europe 1800-1914. New York: Oxford University Press.

[13] Gilpin, Robert. 1981. War and Change in World Politics. Cambridge University Press.

[14] Goldstein, Joshua S. 1988. Long Cycles: Prosperity and War in the Modern Age. New Haven: Yale University Press.

[15] Hurrell, Andrew. 2007. On Global Order: Power, Values, and the Constitution of International Society. Oxford: Oxford University Press.

[16] Iseri, Emre. 2007. Neo-Gramscian Analysis of US Hegemony Today. School of Politics, International Relations and the Environment (SPIRE), Keele University, U.K.

[17] James, Petras \& Morris, Morley. 1995. Empire or Republic?. New York: Routledge.

[18] Johnson.Chalmers 2004. The Sorrows of Empire. Militarism, Secrecy, and the End of the Republic. London: Verso.

[19] Keohane, Robert. 1984. After Hegemony: Cooperation and Discord in the World Political Economy. Princeton, $\mathrm{NJ}$ : Princeton University Press.

[20] Keohane, Robert O. \& Nye, Joseph S. 1977. Power and Interdependence: World Politics in Transition, Boston: Little, Brown, Cop.

[21] Nye, Joseph S. Jr. 2002-3. "Limits of American Power", Political Science Quarterly, Vol. 117, No. 4.

[22] Mearsheimer, John J. 2001. The Tragedy of Great Power Politics. New York: Norton.

[23] O'Brien, Patrick Karl \& Clesse, Armand (eds.). 2002. Two Hegemonies. Britain 1846-1914 and the United States 1941-2001. Aldershot: Ashgate.

[24] Strange Susan. 1988. "The Future of the American Empire", Journal of International Affairs, 42 (1).

[25] Shalom Shephen S. 1993. Imperial Alibis. Rationalizing U.S. Intervention after the Cold War. Boston: South End Press.

[26] Waltz, Kenneth N. 1979. Theory of International Politics. Boston: Addison-Wesley. 